be satisfied by the proof of efficacy (as distinct from safety) required of a new drug.

Two other considerations arise. First, compounds offered as new medicines whose design is based on a testable physiological rationale deserve an inside track a partial presumption of efficacy. That is already an important issue in biotechnology, where many of the compounds waiting in the wings for approval are synthetic versions of naturally occurring proteins, but the queue will become more clamant when more is known of the natural function of genes that, in mutated forms, are linked with important genetic diseases. If, for example, further study and understanding should suggest that there is a replacement therapy for Alzheimer's disease, what formal proof of efficacy would be considered necessary?

The second new opportunity is offered by means in which the design of clinical trials can be made less formal. 'Meta-analysis' is the slogan. The truth is that once the safety of a proposed new medicine has been established, an assessment of its effectiveness can be reached by the careful gathering of data in its tentative use. The outcome is neither as clean nor as decisive as that from a regular clinical trial, but none the less useful on that account. A few exercises of this kind might enable FDA (and similar organizations elsewhere) further to speed up the approval of new drugs. The difficulty, for the radical wing in the US Congress, is that neither of these opportunities can be enshrined in new legislation, but must be decided by a technically expert organization - one like FDA, for example.

\section{Care in the community}

There will be no quick answer to the British government's call for better care for the psychiatrically ill.

THE British government's Department of Health has woken up to a scandal that has been simmering away for the past four years - the plain truth that its humane programme for moving people with chronic psychiatric illness from long-stay hospitals into the community at large is not working as intended. Last week, in the wake of two critical reports by differently constituted teams of inspectors, the minister at the department, Mr Gerald Malone, wrote to Britain's hospital trusts urging them to do better. He is right to ask. Whether he or his successors will be satisfied with the response is another matter.

That the policy of community care is enlightened is beyond dispute. In the bad old days, institutionalization was a disease in its own right, but in the absence of palliatives of psychiatric illness, also a necessity of a kind. Now that manic depression and clinical depression are reasonably well dealt with by means of drugs, and even schizophrenia is controlled by the phenothiazines and their derivatives, it makes good sense that those affected should live in circumstances comparable with those that others of their age enjoy. For any government, community care also offers potentially huge economic benefits; even psychiatric hospitals are expensive to staff and run, while circumstances usually dictate that they should be a public expense. So there is nothing wrong with the ambition that most of those suffering from psychiatric illness should live in the community rather than in hospitals. The difficulties lie in the way in which the policy is carried out.

When the British version of these arrangements was decreed in 1990, it was intended that health authorities and the social services departments of local authorities should devise a joint plan for dealing with the community care of psychiatric patients in their areas. The hope was that there would also be plans for individual patients, offering them programmes of health care, social support and even occupational activity. Last week's report of the Department of Health's own Social Services inspectorate is based on five local-authority social services departments; it says that only one of the five departments had drawn up such a plan, and that even that had been in place for just over a year.

Shameful though that may seem, it is not surprising (nor at odds with anecdotal evidence emerging in the past few years). The Health Service has been in the throes of huge administrative upheaval and in no position to seek out extra work to do, while even those local authorities with expertise in, say, the care of the elderly have not known enough to anticipate the needs of the psychiatrically ill. And among those, it is plain the people with schizophrenia habitually draw the short straw; the Department of Health's Clinical Standards Group (which acts as a kind of auditor of clinical standards) based a detailed survey of the treatment of schizophrenia in eleven health-service administrative units; none was found to be unequivocally "good", although four approached that ranking. Others were frankly "poor" in the quality of the care they provided for schizophrenia.

Extenuating circumstances abound. The administrative changes of the past few years have not helped. The attention paid to the needs of psychiatric patients as distinct from other claimants on public services almost inevitably depends on the fuss that individuals make. And psychiatric illness is still in many places a tainted kind of disability. But the real difficulty is the lack of adequately trained people able and willing to work peripatetically, as community care requires. Sadly, for the psychiatrically ill, that deficiency will not be quickly remedied. When they are found in sufficient numbers, they will turn out to be expensive. Then the government will be wondering whether it can afford the extra cost, and its critics will be saying that it cannot afford not to afford it.That is at least a tangible difficulty. The less tangible, and therefore the less easily remediable, is the persisting suspicion of psychiatric illness even in enlightened administrations such as the British. People with schizophrenia, who are notoriously awkward customers, are especially likely to be short-changed. But wishing that they would go away will serve no purpose. The lifetime suicide rate may be 15 per cent, but numbers are constantly renewed. 